\title{
The Affective (Re)turn and Early Modern European History \\ An Afterword
}

\author{
Ananya Chakravarti \\ Abdelhadi H. Taher Professor in Comparative Religion \\ and Assistant Professor, American University in Cairo
}

"Feelings seem like made-up things, though I know they are not."
—Brenda Shaughnessy, Our Andromeda

T he call to attend to a history of affect is hardly a new one in the profession: in 1941, in a classic essay entitled "La sensibilité et l'histoire: Comment reconstituer le vie affective d'autrefois?," Lucien Febvre laid out an agenda for just such a historiographical turn. His reasoning, however, had less to do with the need for a history of affect per se than with the belief that the history of ideas or of institutions, both of them mainstays of traditional historiography, "are subjects that the historian can neither understand nor make understood without this primordial interest that I call the psychological." ${ }^{1}$ In a perceptive review essay of the historiography of emotions that marked the beginning of the current affective turn in historical inquiry, Barbara Rosenwein argued that Febvre's turn toward such a history was less a repudiation of the political focus of history than a belief born from observing the rise of Nazism: "politics itself is not rational, not unemotional." As Rosenwein notes, Febvre answered the skeptics in his own essay: "The history of hate, the history of fear, the history of cruelty, the history of love; stop bothering us with this idle chatter. But that idle chatter ... will tomorrow have turned the universe into a fetid pile of corpses." 3

Febvre's call was answered by many historians, although not always in explicit form. In its most important continental form, it has largely been subsumed under the rubric of histoire de mentalité as practiced by the Annales School. ${ }^{4}$ However, the new affective turn in the social sciences and humanities reflects Febvre's own primary concern with the political implications of emotion. Whether it is Brian Massumi's reading of the rise of Ronald Reagan or Sara Ahmed's superb analysis of the public response to terrorism, the turn to affect has allowed a diverse range of scholars to address the "insuf- 
ficiency of what might be called intellectualist and deliberationist models of thinking," particularly in explanations of contemporary political life. ${ }^{5}$ More crucially, it has situated the affective life squarely outside the confines of individual subjectivity.

There is, however, another and older genealogy for the historiographical turn toward affect, one that might be more pertinent for the collection of articles presented here. The first of these forbears is the great Dutch historian and Indologist Johan Huizinga, whose account of the autumn of the Middle Ages was first published in 1919. ${ }^{6}$ The second is the sociologist Norbert Elias. His classic work, Über den Prozess der Zivilisation, was first published to relative oblivion in 1939, before its recuperation in Germany in 1969, when the work was reissued. ${ }^{7}$ It was not until 1978 that the Anglo-American academic world came to read The Civilizing Process and finally established Elias, then an octogenarian, as one of the most important sociological thinkers of the last century.

The peculiar poignancy of Johan Huizinga's work lies in his weighty sense that Western modernity had come at the expense of deep cultural loss. Nowhere is this more apparent than in his conclusion to his wide-ranging and erudite essay on the play element of culture, first published in Dutch in 1938 as Homo Ludens: Proeve Ener Bepaling van het Spelelement Der Cultuur. ${ }^{8}$ In an essay that drew from his deep knowledge of the vast span of European history as well as Indology, Huizinga concluded that he lived in an age of puerilism in which the ancient spirit of play, which encompassed ritual and recreation and had nourished human civilization from its origins, had died. It is perhaps his own sense of loss, of living in a more "civilized" but less vivid world, that invested the opening of his most famous and enduring work on the waning of the medieval world its haunting beauty and resonance.

Huizinga's own disappointment at the scientistic rationalism of fin de siècle modernity led him to seek the heart of medieval culture not in thought but in feeling. As he put it,

Modern man cannot usually represent the unrestrained extravagance and inflammability [ontvlambaarheid] of the medieval mind. One can project an image of a piece of medieval history from charters or official documents [de oordkonden] that seems just like eighteenth-century ministerial or diplomatic politics. But such a picture is missing one weighty element: the brilliant color of the violent passion [geweldigen hartstocht] that inspired both the people and the princes. Without a doubt, that element is still present in politics, but it finds now more brakes and impediments, its hundreds of ways guided into fixed paths [vaste banen] by the complex mechanism of communal life. In the fifteenth century, a degree of immediate affect still came to be expressed in the political act, which broke through both utility and calculation. When that affect was paired with a sense of power, as in the case of the princes, it worked doubly violently. ${ }^{9}$

The critique was both methodological and substantive: Huizinga's attention to sources produced outside the official political sphere or high culture, 
and especially his use of artistic works, was crucial to his project. Nonetheless, his reading of medieval history was far from apolitical; rather, he sought to show that to understand medieval power, it was imperative to understand medieval passions. Indeed, Huizinga's belief that the modern era comes at the tail end of a historical process in which the passions have been restrained and guided by communal life foreshadows Norbert Elias's framework of the civilizing process, to which we will return.

In using artistic sources for the history of emotions, Huizinga was aware of the conceptual traps posed by such material. In his exploration of the conventions of courtly love, Huizinga states the problem of using aesthetic sources for social history thus: "It is from literature that one must learn to understand the erotic forms of a period but it is in life itself that one must imagine them." ${ }^{10}$ Still, as Huizinga acknowledged, "it is very difficult to see through the veils of poetry." ${ }^{11}$ Even when an account of love claimed for itself the truth of autobiography, the literary conventions of the day structured the telling. Huizinga sought to solve this conundrum by triangulating sources, considering not merely the ballads of troubadours but also the rare example of an autobiographical account of a romance and even an instruction manual for courtly women on the correct handling of love affairs. Eventually, however, he posited a chasm between the ideals of (literary) love and the cruel realities of social reproduction.

Huizinga's sophisticated skepticism regarding the transparency of artistic objects as sources for social history is nowhere more apparent than in the chapter he devotes to art in life. The most interesting element of this chapter is his attention to the aesthetic standards of the period under study: "The consciousness of aesthetic pleasure and its expression in words has developed late. The fifteenth-century man standing in admiration before art can only put it in terms that we may expect from the astonished burgher. He does not yet know even the concept of artistic beauty. The shudder that radiated through him at the beauty of art was converted by him immediately into either pious repleteness [godsvervuldheid] or a sense of well-being [levensbehagen]." ${ }^{12}$ One may wonder if his Indological background might have contributed to Huizinga's awareness of the relatively underdeveloped nature of medieval aesthetic theory. Certainly, this is a world apart from the prodigious theorization of aesthetics (rasa) and affect (bhāva) and their complex relationship in Sanskrit knowledge systems. The medieval European man, by contrast, has recourse only to vague emotion as a response to art. Regardless, what is of continued methodological import here is Huizinga's attention to the distinction between affect and aesthetics and his chariness at making the easy leap from aesthetic source to social history.

It is intriguing to note that over half a century later, the feminist historian Joan Kelly, using similar sources and without eliding the difference between literary topoi and social reality, arrives at strikingly more radical conclusions than Huizinga regarding medieval courtly love: 
The sexual nature of courtly love, considered together with its voluntary character and the nonpatriarchal structure of its relations, makes us question what it signifies for the actual condition of feudal women. For clearly it represents as ideological liberation of their sexual and affective powers that must have some social reference. This is not to raise the fruitless question of whether such love relationships actually existed or they were mere literary conventions. The real issue regarding ideology is, rather, what kind of society could post as a social ideal a love relation outside of marriage, one that women freely entered and that, despite its reciprocity made women the gift-givers while men did the service. ${ }^{13}$

By contrast, during the Italian Renaissance, Kelly argues, the structures of medieval society that allowed for the imagining of such an ideal of love did not evolve to afford women greater status and opportunities. Kelly tracks this foreclosing of women's social possibilities by tracing the changing imagination of the love relation, couched now in terms of chastity and female dependency.

Gabriela Zarri's article for this special issue in a sense confirms and deepens Kelly's insight, in part through an expansion of Huizinga's exploration of the affect and aesthetics of love beyond his own framework, through the addition of a third element: the attention not merely to the history of sentiment but to the history of the senses.

Like Huizinga, Zarri walks the difficult line between the history of aesthetics and the history of affect by triangulating sources, using not only literary and pictorial representations of love, but also self-reflexive theoretical treatises on the topic. However, whereas Huizinga does no more than imagine the stunned medieval burgher's sensual apprehension of art and his inarticulate affective response to it, Zarri finds a way to articulate the connection between the senses and sentiment historically. The medieval distrust of the senses as potentially dangerous eventually gave way to a new valorization of the senses as "vehicles of the love of God and of one's neighbors." The process paved the way for what we may recognize as the modern conception of love, in which the sensual and intellectual intermingle, a love that involves "the senses and the will." In doing so, Zarri complicates Kelly's conclusion of the foreclosing of the social possibilities for women during the Renaissance, finding, for example, that for women like Elena Duglioli, the new conception of love actually allowed new roles and modes of achieving social status. In embodying the Renaissance ideal of chaste love, this time pursued within marriage, Duglioli could become the focus of a religious cult. Furthermore, Zarri pushes back our usual periodization for the birth of romantic love as a product of the nineteenth century to the early modern era and suggests a potential solution to the problem Huizinga identified in the chasm between aesthetics and affect by forging a bridge through the history of the senses.

If the ghost of Huizinga may still be discerned at the banquet of current inquiries into the history of emotions through the methodologies of 
cultural and art history, Elias is perhaps even more au courant in terms of the current affective turn. This is in no small part because of the resonances between his work and that of Gabriel Tarde, the French social psychologist whose posthumous revival has been crucial to the affective turn and for the attempt generally to navigate away from the intellectual shallows into which Tarde's great rival, Émile Durkheim, had eventually led sociology to founder. ${ }^{14}$ It was Tarde's attention to the psychological, a term that, after Durkheim, would come to elicit discomfort, if not outright embarrassment, among the more scientistic students of human society, that scholars of affect would eventually find so fruitful. If Durkheim had formulated sociology as the study of the constraining imposition of social structures upon the formation of individual subjects, Tarde had sought to reject the foundational dualism of individual and society upon which Durkheim's project rested. For Tarde, the social was but a "phantom ... [revived] at will, to which we attribute all sorts of marvelous virtues in order to dispense with recognizing the real geniuses who really do good, by whom we live, in whom we move, without whom we would be nothing." ${ }^{15}$ Thus, the separation of sociology and psychology in the Durkheimian fashion is the propagation of a false dichotomy. An obvious corollary here is that affect and emotion, which in a Durkheimian schema may be relegated to the realm of individual psychology, were now fitting subjects for sociological inquiry. ${ }^{16}$

For Tarde, the study of the social must be located at the level of individual interaction. The echoes of this interactional model, as well as the influence of philosophers of movement like Henri Bergson, can be seen in Elias's own conception of a figurational sociology, which retained the inherent dynamism of social life that "systemic" conceptions often stultified:

The image of the mobile figurations of interdependent people on a dance floor perhaps makes it easier to imagine states, cities, families, and also capitalist, communist, and feudal systems as figurations. By using this concept, we can eliminate the antithesis, resting finally on different values and ideals, immanent today in the use of the words, "individual" and "society." One can certainly speak of a dance in general, but no one will imagine a dance as a structure outside the individual or as a mere abstraction. The same dance figurations can certainly be danced by different people; but without a plurality of reciprocally orientated and dependent individuals, there is no dance. Like every other social figuration, a dance figuration is relatively independent of the specific individuals forming it here and now, but not of individuals as such. ${ }^{17}$

Yet, in arguing for the primacy of the individual, Tardean sociology continued to fall under what Elias characterized as the tyranny of the Western intellectual tradition's image of man as homo clausus. This is the conception of the single and self-contained individual as the subject of knowledge, the isolated ego in a sea of other such entities constantly beset by crippling epistemological doubt regarding the very possibility of (apprehending) external re- 
ality. ${ }^{18}$ Elias instead sought to make the starting point of sociological inquiry homines aperti, replacing the monadic notion of the individual with an open, porous, and processual model of persons formed in mutual interaction. Indeed, homo clausus, far from being a philosophical universal, was a historical step in the Western civilizing process, in which the increasing social constraint toward self-restraint eventually produces the sense of a self-enclosed "I" gazing out upon the world as a dominant form of self-experience. As Elias puts it: "Transformations of consciousness of this kind are both historical, in that whole societies have undergone or are still undergoing them today, and personal, in that every child undergoes them in growing up." 19

This relationship between changes in personality structure and in human social relationships is at the heart of Elias's notion of the civilizing process. He conceives of this process of social evolution neither as the inexorable drift toward rationalization in the Weberian sense, nor as the manifestation of material forces. Elias began with the observation that the nineteenthcentury West's inherent sense of superiority over not only its own lower classes but the natives of other lands, who were to be colonized in order to be civilized, rested on a historical amnesia. The very process by which Western standards of behavior were considered marks not merely of civility but of civilization had been forgotten. Elias wished to reclaim this process by tracking long-term changes in behavior, habitus, and power dynamics through his analysis of conduct books for the elites and aspiring elites of medieval Europe, focusing particularly on the most "natural" of human functions to which all humans are biologically bound. Elias showed how many of these functions retreated away from social life and became associated with feelings of shame. In other words, the social constraints learned painfully but a generation before would come to be so deeply habituated in their descendants as to be repressed into the unconscious.

Moreover, these processes were intimately tied to power: as the medieval state pacified ever-expanding territory and brought more people into complex webs of interdependence through increasing urbanism, trade, and growing bureaucracies and military organizations, there was increasing pressure to consider the consequences for others of one's actions. This increasing consideration of others, "psychologization", combined with another process, rationalization, in which people oriented themselves increasingly away from short-term affect toward longer-term models of reality in marshaling behavior. Thus, the tendency toward self-restraint was produced through social constraint. Here, Elias's analysis of shame and embarrassment is exemplary. Shame is generated by the sense of having offended good manners and embarrassment by the observation of another committing such a transgression. Elias demonstrated how, as rules of manners became more expansive and pervasive, the occasions for feeling these emotions increased. In other words, Elias demonstrates the sociogenesis for what appear to be personal emotions.

As I hope this brief excursus into Elias's work amply demonstrates, the articles in this special issue point toward a similar set of sociological axioms 
regarding the emotional life of past societies. Take, for example, the seemingly natural and transcultural sentiment of the fear of dying that preoccupies Adriano Prosperi. Beginning with the idiosyncratic and deeply personal emotions of his protagonist, Giovambattista di Bindaccio Ricasoli Baroni, Prosperi demonstrates the sociogenesis of the emotions that haunted his troubled life. The terror and shame he felt, far from being the product of a single pathological mind, were rather an understandable emotional response to the particular figurations of power and class of the period.

Yet, where Elias was concerned primarily with the normative, our authors are interested in the transgressive, the pathological, and the exceptional. It is no coincidence that Prosperi, Giuseppe Marcocci, and Mariana Labarca all rely upon legal documentation-the records of an inheritance trial, interdiction procedures, even the proceedings of criminal trials-in their reconstructions of the emotional histories of early modern Italy. Yet, in doing so, our authors restore to their historical actors the dignity and autonomy that the society of their own times had stripped off them. Prosperi rescues his protagonist from the stigma of mental illness by exploring the reasonable bases for his seemingly pathological emotions.

In contrast, through an analysis of emotional standards for mental incapacity in the elderly in eighteenth-century Tuscany, Labarca does not seek to show how seemingly pathological emotions were based in social realities, but rather how social realities, such as intergenerational conflict, produced the standards of emotional pathology. Moreover, whereas Elias implies that emotional learning effected by the previous generation became habitus for their descendants, Labarca shows instead that this process is by no means unidirectional; neither is it a smooth and cumulative relay of stores of social knowledge across human time, but a process that involves negotiation and conflict across generations.

The right to passion, the right to feel and express emotion, is the field of intense social conflict and negotiation. Marcocci's startling exploration of the infamous case of the homosexual marriages of sixteenth-century Rome serves as a potent reminder of this fact. Like Labarca, Marcocci provides a corrective to Elias's rather unidirectional emphasis on the sociogenesis of emotion, this time through an exploration of the extent to which those who experience emotions not sanctioned or even censured by society may still seek socially acceptable forms of expression. Here, social constraint, instead of producing emotional self-restraint, as Elias would expect, produces instead a socially subversive performance of emotion. If marriage increasingly became a socially accepted locus for the expression of romantic love, as Zarri shows, then the performance of homosexual marriage in early modern Rome was a radical means of declaring the existence of romantic love between men, a possibility denied by the social standards of emotions then (and, in many places, even now). In doing so, Marcocci revises the accepted periodization, after Foucault, of homosexuality as a specific identity, transforming it from a nineteenth-century invention to a phenomenon of far older provenance. 
The condemned bridegrooms of Rome guard those of us engaged in examining the historical and cultural production of emotion against Elias's overdetermination of the affective life as a social phenomenon. They alert us to the possibility that not only might affect occasionally exceed social origination and constraint; it could also possess a radical and potentially emancipatory power for precisely this reason.

In a rather different key, Jennifer Hillman's moving article on the relationship between Anne-Marie Martinozzi and her husband, Armand de Bourbon, also points to what is perhaps the most unrealized and potentially productive aspect of Elias's work: the question of the production of a history that is not based upon the assumed character of the historical actor as a monadic individual. Put another way, Hillman provides a concrete historical example of Elias's postulated homines aperti in the Prince and Princess of Conti. Spiritual lovesickness was an index not merely of an absent lover and devotee, but a sign of the process of the coproduction of persons that was entailed in the practice of copenitence in early modern Catholic spiritual direction. Martinozzi experienced the absence of her husband not merely as the loss of another person, but also as a profound interior alienation. Conversion-that is, the creation of the pious person-was a process inextricably bound with other persons. Indeed, the strong mystic vein Hillman uncovers in the lifeblood of Martinozzi's emotions is merely another indication of the ways in which the rigorist person was profoundly not the "individual" of post-Kantian fantasy.

The articles gathered here are certainly not a comprehensive overview of the emotional landscape of early modern Europe. Focusing on the Catholic world, one can well imagine that evidence from the other side of the confessional divide of post-Reformation Europe may reveal a very different picture. Despite this, these articles, beyond the specific richness of the empirical evidence they provide, point us toward new vistas in the exploration of the history of emotions in Europe, beyond the horizons that Huizinga and Elias had first glimpsed. Yet, in the myriad soundings of their work that continue to echo in current research, one may find a salutary lesson in the rich theoretical possibilities that a return to our intellectual forbears may reveal to modern historians.

\section{Notes}

1. Lucien Febvre, “La sensibilité et l'histoire: Comment reconstituer la vie affective d'autrefois?," Annales d'histoire sociale 3, nos. 1-2 (1941): 5-20, quotation at 19.

2. Barbara Rosenwein, "Worrying about Emotions in History," The American Historical Review 107, no. 3 (2002): 822.

3. Febvre, "La sensibilité et l'histoire," 19.

4. The third generation of Annales School historians best exemplified this concern. See, for example, Emmanuel Le Roy Ladurie's exquisitely observed portrait of 
the medieval village of Montaillou and Phillipe Ariès's study of the long history of changing European attitudes toward dying. Emmanuel Le Roy Ladurie, Montaillou, village Occitan, de 1294 à 1324 (Paris: Gallimard, 1975); Phillipe Ariès, L'homme devant la mort (Paris: Le Seuil, 1977).

5. William E. Connolly, Neuropolitics: Thinking, Culture, Speed (Minneapolis: University of Minnesota Press, 2002), 10. See also Brian Massumi, Parables for the Virtual: Movement, Affect, Sensation (Durham, NC: Duke University Press, 2002); Sara Ahmed, The Cultural Politics of Emotions (Edinburgh: Edinburgh University Press, 2004).

6. Johan Huizinga, Herfsttij der Middeleeuwen: Studie over levens-en gedachtenvormen der veertiende en vijftiende eeuw in Frankrijk en de Nederlanden (Haarlem: Tjeenk Willink, 1919). The first English translation was published in 1924 as Johan Huizinga, The Waning of the Middles Ages: A Study of Forms of Life, Thought, and Art in France and the Netherlands in the Dawn of the Renaissance, trans. Fritz Hopman (London: Edward Arnold, 1924). This elegant abridged adaptation, however, was far from a faithful translation of the Dutch original.

7. Norbert Elias, Über den Prozess der Zivilisation: Soziogenetische und psychogenetische Untersuchungen (Basel, 1939). The first English translation was published as Norbert Elias, The Civilizing Process: Sociogenetic and Psychogenetic Investigations, Vol. 1, The History of Manners, trans. Edmund Jephcott (Oxford: Basil Blackwell, 1978); Vol. 2, State Formation and Civilization (Oxford: Basil Blackwell, 1984).

8. Johan Huizinga, Homo Ludens: Proeve Ener Bepaling van het Spelelement Der Cultuur, in Johan Huizinga, Verzamelde werken V. Cultuurgeschiedenis III, ed. L. Brummel et al. (Haarlem: Tjeenk Willink, 1950), 26-246.

9. Huizinga, Herfsttij der Middeleeuwen. Here and below the quotations are taken from the Project Gutenberg text, http://www.gutenberg.org/files/16829/16829h/16829-h.htm. All translations are the author's.

10. Ibid.

11. Ibid.

12. Ibid.

13. Joan Kelly, "Did Women Have a Renaissance?," in Woman, History, and Theory: The Essays of Joan Kelly (Chicago: University of Chicago Press, 1984), 26. I am grateful to Linda Mitchell for pointing out this comparison.

14. The debate between the two great sociologists between 1902 and 1904, which marked the eclipse of Tarde's influence, was quite literally re-enacted in a meeting at Cambridge University by Bruno Latour and Bruno Karsenti in 2008. The text of the historical debate has been published: Eduardo Viana Vargas et al., "The Debate between Tarde and Durkheim," Environment and Planning D: Society and Space 26: 761-777.

15. Gabriel Tarde, On Communication and Social Influence (Chicago: University of Chicago Press, 1969), 124.

16. As Durkheim once put it, "every time that a social phenomenon is directly explained by a psychological phenomenon, we may be sure that explanation is false." See Émile Durkehim, Les règles de la méthode sociologique (Paris: Alcan, 1895), 128-129.

17. Norbert Elias, The Civilizing Process (Oxford: Basil Blackwell, 1994), 214.

18. Norbert Elias, The Society of Individuals, trans. Edmund Jephcott (Oxford: Basil Blackwell, 1991), 91-94, 101-103.

19. Ibid., 105. 